\title{
Impact of Oil Price and Shocks on Economic Growth of Pakistan: Multivariate Analysis (Sectoral Oil Consumption)
}

\section{Nazir S and Hameed $T^{\star}$}

Pakistan Institute of Development Economics (PIDE), Quaid-i-Azam University Campus, Islamabad, Pakistan

\begin{abstract}
Oil is becoming the most prominent indicator of economic growth in Pakistan with increase of its demand. Also oil prices are doing their main contribution to impact the GDP of Pakistan including different shock dummies in data. In this study, Cobb-Douglas production function has used to construct three models by introducing three major sectors of oil consumption of Pakistan (Transport, Power and Industrial sector oil consumption) and Pakistan's oil price variable to investigate the impact on GDP. ADF(1979) and Johansen Maximum Likelihood method of cointegration (1988) are used to test the order of integration, Long run and short run dynamics between variable respectively using annual data since 1972-2011 in context of Pakistan. Through examining the results, the long run and dynamic relationship has detected for all the variables except industrial oil consumption and oil price variables for model has no short run impact on GDP. Oil prices impacting real GDP negatively in long run but positively in short run.
\end{abstract}

Keywords: Sectoral oil consumption of Pakistan; Oil shocks; Johansen maximum likelihood method; Oil prices; Time series

\section{Introduction}

Since 2010 oil demand has increased rapidly in all over the world because of world oil price has driving down [1]. The existing literature has suggested the many possible impacts of oil shocks on the economic growth [2]. Increase in the oil price cause to increase in the production cost, import bills and price of petroleum products, so the decline in the productivity due to increasing cost of input (oil) cause decline in the consumption level, investment and consequently in economic growth [3]. So oil price shocks limit the oil consumption which can be lead to lessen the economic growth. Consumption of energy plays vital role in enhancing the growth of economy [4]. Oil consumption plays crucial role in every sector of economy i.e. transport, power sector and industrial sector [5]. There is difference in results of causal relationship related to energy-growth model of developed and developing country like Pakistan. Developed countries show more intensity toward energy consumption [6]. Many studies have been done on causality issue of energy and economic growth. But still there is dilemma to conclude the reliable result. Majority of studies are available related to oil prices, its consumption and its impact on the economic growth for developed countries $[7,8]$. But recently there are lots of studies are available on the context of oil prices, its consumption and its impact on the economic growth [4,6,9-19]. All these studies concluded diverse results regarding energy (oil) consumption and growth. These all studies have not given the satisfactory conclusion that which are specific determinants that impacts the relationship between consumption and growth of the economy. But by examining the all studies mentioned above it can be said that difference of result is due to use of different source of data, time span and econometrics techniques these are different for different countries, so results could be inconsistent.

The country like Pakistan whose major imports comprises on oil and oil products and Pakistan is depending heavily on the oil as input in industrial, transport and electricity sector. As many developing countries generate electricity from cheap sources like water, wind etc, but in Pakistan oil is the major source to produce electricity that is costly input. In Pakistan studies were conducted that estimate relationship between use of oil and economic growth specifically [5,20-23]. In these studies three stage Granger causality test and ECM approach has been used to test causality respectively and Johansen cointegration test for cointegration analysis. In these studies oil prices or oil price shock variable has denied, as its very important factor to effect the economic growth. The core objective is to analyze the results of oil prices and oil price shocks on economic growth. We also investigate impact of other shocks on economic growth of Pakistan. The other objective of the study is to investigate the impact of oil consumption on economic growth of Pakistan by using cointegration analysis and dynamic Error Correction Model.

The study is arranged as follows: the section 2 explains the oil sector of Pakistan, section 3 illustrates the methodology which includes sources of data and explanation of Augmented Dickey Fuller test, Johansen cointegration by Maximum Likelihood Method section 4 explains the results and discussion of the analysis. Finally section 5 demonstrates the conclusions of the study.

\section{Salient Features of Oil in Pakistan}

Pakistan has to need a continued long term economic growth of 7 percent to increase its general living standards and meaning full economic development. But it is observed that Pakistan's economy hardly ever grow more than 5 percent since its independence. The economic growth of Pakistan has declined since 2008 and viewed at 2.6 percent. The expected growth in 2012 is around 3 percent which is low then the targeted growth 4.2 percent and meanwhile the continental Asia is expected to grow more than 7.5 percent in that year. Slow macroeconomic determinants have been the main factors of low economic growth.

The world economy has suffered badly due to oil shocks since 1973 .

*Corresponding author: Hameed T, MPhil, Pakistan Institute of Development Economics (PIDE), Quaid-i-Azam University Campus, P.O. Box. 1091, Islamabad Pakistan, Tel: +92 51 9248074; E-mail: sidranazir_shah@yahoo.com

Received July 22, 2015; Accepted August 31, 2015; Published September 07 2015

Citation: Nazir S, Hameed T (2015) Impact of Oil Price and Shocks on Economic Growth of Pakistan: Multivariate Analysis (Sectoral Oil Consumption). Bus Eco J 6 : 182. doi:10.4172/2151-6219.1000182

Copyright: $\odot 2015$ Nazir S, et al. This is an open-access article distributed under the terms of the Creative Commons Attribution License, which permits unrestricted use, distribution, and reproduction in any medium, provided the original author and source are credited. 
There are five main oil shocks in the world which affected the whole universe. Oil shocks can be defined as the oil prices increases enough to effect recession or slow down the economy. Followings are the reasons of oil shocks in the world and can be seen through Figure 1.

It is observed that oil prices in its market place went down but meanwhile, in the context of Saudi its income went upward due to oil extraction and domestic low price. OPEC had set an oil price at 18 dollar per container in December, 1986 but that price was not continued for a long period and decreased in the start of 1987. After that Iraqi and Kuwait war pay an important role to increased oil prices due to instability of oil supply in 1990. But after Gulf war (Kuwait and Iraqi war) the oil price was noticed a considerable decreased till 1994 and reached at the same price which was in 1973. Later then in 1998, the price increased and goes toward revival due to reduced oil supply by OPEC and maintained at the level of 1.72 million containers in April, 1999. In 1982 to 1985, Oil producing and exporting countries (OPEC) has try to allocate a quota among its member countries to maintained the oil supply in the world but they are failed due to not serious action by its members and specially Saudi Arabia, which decreased its oil supply because of decline in oil prices. In the mid1986, they tried to correlate the oil prices with blemish oil market to maintain the oil prices less the 10 dollar per container.

These all shocks have great impact on the GDP of oil importing country, like Pakistan. Other than these external shocks Pakistan oil prices are also affected by the internal shocks due to different natural and political disasters in the country.

In Pakistan three major sector of oil consumption are transport, power generation sector and industrial sector. In 1980s Pakistan economy was growing with the increase in energy demand. If we look at the Figure 2 of oil consumption of Pakistan, it can be seen that, in 1980 to 1990 especially oil consumption has increased, as there was 6\% increase in its import per annum. In 1996 energy consumption has increased as in previous year. Pakistan's biggest consumption is gas after that oil is $2^{\text {nd }}$ major energy component. Total energy consumption decreased from $48 \%$ to $29 \%$ in $2006-07$. So oil consumption in 2000 to 2005 shows drastic negative trend and deceased 3.4\%. During 2005-06 almost 8.4 million tons crude oil is imported. But in 2003-04 it was higher in amount then in 20005-06 that was 16 million tons consumed by transport sector of Pakistan. In 2005-06 55\% of total oil consumption is consumption by transport sector and $29 \%$ and $12 \%$ by power and industrial sector respect ively. In 2008-09 the overall condition of energy consumption was very sever due to high oil prices. That affects Pakistan's macroeconomic and cause inflation, current account deficit, decreasing the purchasing power of poor as well as riches. In 2008-09 the oil consumption was $29 \%$ of total energy consumption.

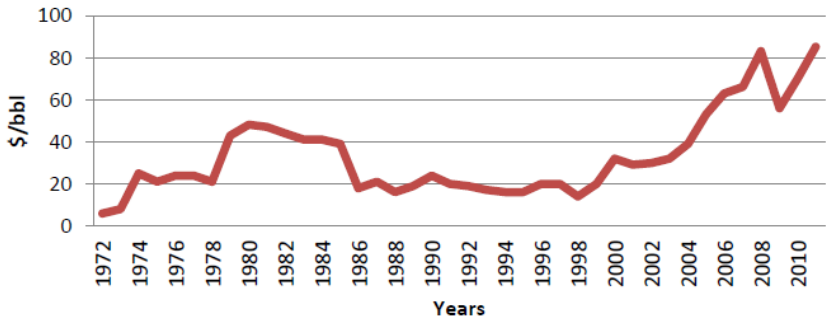

Source: World Bank Data Indicator.

Figure 1: World Crude Oil Price.

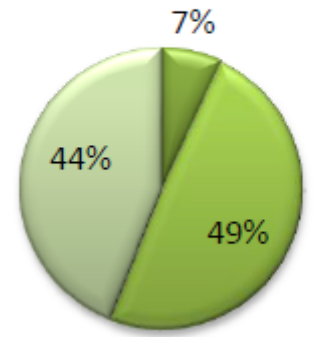

$\square$ industrial

$\square$ transport

$\square$ power

Source: Data taken from Pakistan energy year book by Hydrocarbon Development Institute of Pakistan.

Figure 2: Sectoral Oil Consumption.

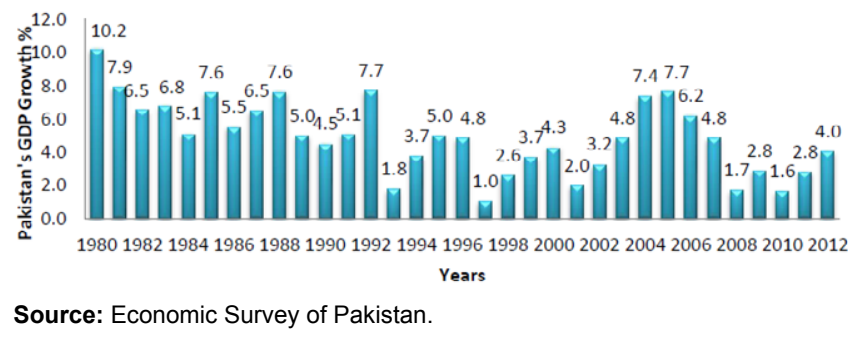

Figure 3: GDP Growth Rate of Pakistan.

In 2011 transport sector, petrol surged $18.1 \%$ due to shortage of gas. Petrol consumption increases $34 \%$ due to load shading of gas sector and gas sector curtailment. In 2011 the percentage of sectoral oil consumption is given below in the Figure 2.

There was increase in the consumption of FO and high speed diesel (HSD) due to increase of power sector needs. But still this sale was less than in 2010. Power sector petroleum consumption decreases $5.7 \%$ in 2011. Oil consumption reaches at 8.4 million tons including industrial sector consumption. In November 2011 oil consumption has increased $11 \%$. The average crude oil production in 2011-12 is 66032 barrel per day. In 2011-12 almost here was $24.4 \%$ growth in the industrial sector of Pakistan and 3.5\% growth in transport sector. Despite all energy shortfall Pakistan oil consumption decreases 3\% in 2012 to 19.1 million tons against 19.7 million tons in 2011. This is $2^{\text {nd }}$ consecutive year in which oil consumption has decreases. This is because due to decrease in FO sale, which comprises of $45 \%$ of total oil consumption of Pakistan. In this year consumption of oil in power generation sector has declines from 7 to 8.4 million tons. If we examine the transport sector of Pakistan, the sale of petrol increased in 2012s was $8 \%$ in 2008 (Figure 3).

Pakistan real GDP grew at higher rate of $8.4 \%$ in 2004-05 as given in Figure 3, due to energy consumption increase it accelerates the economic growth. In 2007-08 high oil prices in the world market cause the decline in the exports that cause to reach the current account deficit at $8.4 \%$ of GDP, which was at $1.8 \%$ GDP in 2003-04. Before 2007-08 the GDP has increased due to oil consumption increase with the high oil prices. In 201, the world oil prices have increased up to $47 \%$ and Pakistan oil prices showed increase of $28 \%$. In May 2011 the world oil price was recorded 115 US $\$ / b b l$ as compared to previous 
year 2010 it was 83 US \$/bbl, so world oil prices showed increase of almost 39\%. Due to increase in world oil prices cause decrease in the oil consumption of Pakistan because Pakistan's oil prices also goes up to $28 \%$ in 2011 .

Pakistan GDP growth in 2009 was $1.7 \%$ but in last five years GDP growth has increases from 3.1\% in 2010 to $3.7 \%$ in 2012 and expected to reach at $4.3 \%$ in 2013. But in comparison with other south Asian countries Pakistan GDP showing less growth, it's due to Pakistan economy is very closely related to world, having external exposure and heavy import of oil products. Oil prices increase effects the macroeconomic factors of Pakistan like; investment, consumption, BOP and unemployment. In 2011-12 the oil import bill reached at $11.14 \$$ billion, there is increase of $38 \%$ as compared with $4.8 \$$ billion in last year 2010-11. Trade deficit also increases in 2011-12 then previous year due to heavy imports. In economic survey of Pakistan (2011-12) it is claimed that Pakistan's economy showed better growth then other developing economies and GDP remained at its high growth of $3.7 \%$ (higher in last three years). But in 2011-12 Pakistan's current account balance is affected due to increase of oil prices Oil prices have also great impact on CPI of Pakistan. That causes the increase in prices of electricity and gas. As we know that Pakistan is oil deficit country and due to increase in import bill, Pakistan has facing increase in circular debt in recent years. Circular debt is because of low refinery utilization, constraint in oil margins, and capability of imports and delay of projects. So there is need to reduce and finally cut down the subsidies to energy sector by government to stop the further increase in circular debt. So, the question is if oil consumption decreased (by $3 \%$ in 201112 ), why shouldn't GDP decreased (as it is $3.7 \%$ in 2012, higher in last three years).

\section{Literature Review}

If we examine the international studies relate to oil consumption, growth and prices it can be seen that literature in context to energygrowth has been initiated with the study of Kraft [12]. It is notice that mostly authors seem interested in finding the causal relationship between energy consumption and economic growth. Many initial studies have done bivariate analysis in this respect, which could generate biased results due to omission of relevant variables. Afterward more complex studies had examined in which aggregate as well as at disaggregate level studies delivered including oil consumption analysis but only few studies are available, such as; multivariate analysis like Levent and Korap, panel data analysis using Hasio Granger causality test as Chenge and Lai [14], maximum likelihood method of cointegration by Johansen [24] and VECM approach as in Soytas and Sari [25], were used in recent international papers. But these studies generated different results from each other even for same sample data as Akarca and Long [26], and very few studies has included the important oil shocks factor in their analysis as in Bekhet and Yusop [13], these results could be different due having different techniques, different sample data, times series properties of the data and different country. So results could be different, although at international level, few studies have used advanced econometric techniques.

If we look up the studies in context of Pakistan, numbers of studies could be found on the issue of energy-growth, in case of Pakistan there are studies at aggregate energy level as well as disaggregate level of energy from these only few studies are available that are specifically on oil consumption and economic growth like Qazi and Riaz [20], and only one study that is on oil consumption and economic growth including major and minor sectors of oil consumption [5]. If we examine the previous study of Zaman et al. [5], that was first study in Pakistan that had investigated the relationship between oil consumption in sectors of Pakistan and economic growth. In previous study oil price variable and shock dummies were not included that could have significant impact on the economy. Oil consumption variables are positively cointegrated with economic growth in Zaman et al. [5] study. But oil consumption variables (including oil sectors) show unidirectional causal relationship by using pair wise Gra nger causality test. In this study Johansen cointegration test has used and found all variables cointegrated. But these results could be biased by estimating single the dynamic equation for aggregate as well as aggregate oil consumption due to multicoliniearity. But in our study dynamic model for total oil consumption will be estimated. Also oil shocks factor has ignored that will be added in our study that have important impact to effect consumption and growth of economy.

So finally it is examined that different cointegration and causality relationships are concluded from different papers of total energy and economic growth including oil consumption- economic growth analysis. Most of studies show that energy (oil consumption) has positive impact on the overall economy.

\section{Methodology}

Neo classical production function $[\mathrm{Y}=\mathrm{f}(\mathrm{K}, \mathrm{L})]$ has used for this study, that is presented by Cobb-Douglas [27], it has been modified by including energy variables for energy-growth model.

Neoclassical economist gave the theory of output (production) function as fellows;

$$
\mathrm{Y}=f(\mathrm{~K}, \mathrm{~L})
$$

Among economists, Georgescu-Roegen [28,29] was the pioneer to remark on the lack of energy variable in the model. The Kraft and Kraft [12] was first to use energy consumption variables in production function to analysis the energy-growth relationship. After that many studies comes in this line, as Khan and Qayyum [10], Lee [16] and Zaman [5] has used in their study. Energy consumption plays very important part on affecting the economy as labor and capital do. In this study oil price of Pakistan has introduced in the model as Bekhet [13] and Saibu [30] used in their study. Oil prices significantly impact on GDP, consumption and overall economy. In literature existing studies like Ahmed [21] has explained various transmission mechanisms for possible impact of oil price shocks on economic growth. First is the classic supply size effect, according to which, increase in oil prices leads to decline in the output level, because oil is considered as the basic input of the production [31]. Higher oil prices would result in the higher output costs, results in lowered production rate and declined growth rate. Second, the demand side effect discusses the adverse effect of oil price shocks on investment and consumption. The major input for the industries is capital that comes from the investments of local and foreign investors. When economic activities are at decline, investors withdraws their investments from markets and take money out of the country and invest in higher profitable and growing economies, resulting in further lowering of production and economic activities in the country [2]. Also Akram [11] has introduced oil price variable in the production function in his study. So above model is modified as follows:

$$
\mathrm{LY}_{\mathrm{t}}=f\left(\mathrm{LK}_{\mathrm{t}}, \mathrm{LL}_{\mathrm{t}}, \mathrm{LP}_{\mathrm{t}}, \mathrm{LOC}_{\mathrm{t}}, \mathrm{D}_{\mathrm{t}}, \mu_{\mathrm{t}}\right)
$$

Where;

$\mathrm{LY}_{\mathrm{t}}=\mathrm{Log}$ of Gross domestic product, real data of GDP taken as the 
proxy of economic growth.

$\mathrm{LK}_{\mathrm{t}}=\mathrm{Log}$ of gross fixed capital formation divided by GDP is used as the proxy of the capital stock $(\mathrm{K})$ as many paper has used this proxy for capital stock $(\mathrm{K}),[10,16,25]$.

$\mathrm{LL}_{\mathrm{t}}=\mathrm{Log}$ of labor force.

$\mathrm{LP}_{\mathrm{t}}=\mathrm{Log}$ of average oil prices of Pakistan.

LOC $_{t}=$ Log of oil consumption that includes three major sectors (transport, power sector and industrial sector) of Pakistan.

$\mathrm{D}_{\mathrm{t}}=$ Dummy variable for in cooperating the effect of oil prices shocks to Pakistan's economy.

$\mu_{\mathrm{t}}=$ Error term, that is normally distributed with zero mean and constant variance $\left(0, \sigma^{2}\right)$.

It is assume that all variables are non- stationary and have long run relationship between economic growth and its determinant.

General model of this study was specified above in equation (6.2). For the next analysis of this study there is needed to construct the vector auto regressive (VAR) model constructed for equation (6.2) given below in equation (6.3):

$$
\begin{aligned}
& X_{t}=\sum_{i=1}^{k} \delta X_{t-1}+\mid \gamma D_{t}+\alpha+\mu_{t} \\
& \therefore \mu_{t} \sim N\left(0, \sigma^{2}\right)
\end{aligned}
$$

Where, $\mathrm{X}_{\mathrm{t}}$ is vector of variables (i.e. $\mathrm{LY}, \mathrm{LL}, \mathrm{LK}, \mathrm{LP}, \mathrm{LOC}$ ) a $5 \times 1$ vector of integrated of order one $\mathrm{I}(1)$ taken as endogenous variables, $\mathrm{D}_{\mathrm{t}}$ is the vector of exogenous variables, $\alpha$ is constant and $\mu_{t}$ is iid $\left(0, \sigma^{2}\right)$.

Assuming the variables are non-stationary and they have long run relationship among each other, we specify dynamic ECM model as:

$$
\begin{aligned}
& \Delta X_{t}=\mu+\gamma t+\sum_{i=1}^{p} \Gamma_{i} \Delta X_{t-i}+\Pi E C M_{t-1}+\lambda D_{t}+v_{t} \\
& \therefore \mu_{t} \sim N\left(0, \sigma^{2}\right)
\end{aligned}
$$

In equation (6.4), $\Pi=\alpha \beta^{\prime}$ and $\alpha$ is speed of adjustment of matrix and $\beta^{\prime}$ is matrix of long run coefficients. ПXt-1 integrated of order zero I ( 0$)$ and negative for having long cointegration relationship. $\sum_{i=1}^{p} \Gamma_{i} \Delta X_{t-i}$ this term of model indicates short run part. $\lambda$ ndicates coefficient of shock dummies, $\gamma$ coefficient of time trend of model $\mu$ and vt are intercept and error term of the model respectively that are normally distributed as zero mean and constant variance.

Through the value of $\Pi$ it can be shown that with how much speed model is converges toward equilibrium or we can say that error is correcting with speed of the $\Pi$. Its value also confirms our long run relationship.

ECM models of three sectoral oil consumption of Pakistan re given below; these will be estimated for finding the results of our study:

\section{Transport oil consumption and growth}

$$
\begin{aligned}
& \Delta L Y_{t}=\beta_{0}+\text { trend }+\Pi_{1} E C M_{t-1}+\sum_{i=1}^{m} \beta_{1 i} \Delta L Y_{t-1}+\sum_{i=1}^{n} \beta_{2 i} \Delta L K_{t-1}+\sum_{i=1}^{o} \beta_{3 i} \Delta L L_{t-i}+ \\
& \sum_{i=1}^{p} \beta_{4 i} \Delta L P_{t-i}+\sum_{i=1}^{q} \beta_{5 i} \Delta L T R A N S P_{t-1}+\phi D_{i}+\mu_{0 t}
\end{aligned}
$$

The second dynamic model for transport oil consumption and growth is given above. So the expected relationship between the variables could be,

$$
\beta_{0}>0, \beta_{1 i}>0, \beta_{2 i}>0, \beta_{3 i}>0, \beta_{4 i}<0, \beta_{5 i}>0, \Pi_{1}<0 \text { And } \phi<0
$$
. $\mu 0 \mathrm{t}$ error term of the dynamic model normally distributed as $\left(0, \sigma^{2}\right)$.

\section{Power sector oil consumption and growth}

$$
\begin{aligned}
& \Delta L Y_{t}=\delta_{0}+\text { trend }+\Pi_{2} E C M_{t-1}+\sum_{i=1}^{m} \delta_{1 i} \Delta L Y_{t-1}+\sum_{i=1}^{n} \delta_{2 i} \Delta L K_{t-1}+\sum_{i=1}^{o} \beta_{3 i} \Delta L L_{t-i}+ \\
& \sum_{i=1}^{p} \delta_{4 i} \Delta L P_{t-i}+\sum_{i=1}^{q} \delta_{5 i} \Delta L P W G_{t-1}+\theta D_{i}+\mu_{0 t}
\end{aligned}
$$

Dynamic model for power sector oil consumption and growth will be estimated as above.

Whereas anticipated relationship between variables might be, $\delta_{0}>0, \delta_{1 i}>0, \delta_{2 i}>0, \delta_{3 i}>0, \delta_{4 i}<0, \delta_{5 i}>0, \Pi_{2}<0$ and $\theta<0 . \quad \mu 0 \mathrm{t}$ error term of the dynamic model normally distributed as $\left(0,{ }^{2}\right)$.

\section{Industrial oil consumption and growth}

$$
\begin{aligned}
& \Delta L Y_{t}=\lambda_{0}+\text { trend }+\Pi_{2} E C M_{t-1}+\sum_{i=1}^{m} \lambda_{i} \Delta L Y_{t-1}+\sum_{i=1}^{n} \lambda_{2 i} \Delta L K_{t-1}+\sum_{i=1}^{o} \lambda_{3 i} \Delta L L_{t-i}+ \\
& \sum_{i=1}^{p} \lambda_{4 i} \Delta L P_{t-i}+\sum_{i=1}^{q} \lambda_{5 i} \Delta L I N D_{t-1}+\omega D_{i}+\mu_{0 t}
\end{aligned}
$$

Finally, thedynamicmodelforindustrialoilconsumptionandgrowth will be estimated as above. While the possible relationship between variables can be, $\lambda_{0}<0, \lambda_{1 i}>0, \lambda_{2 i}>0, \lambda_{3 i}>0, \lambda_{4 i}<0, \lambda_{5 i}>0, \Pi_{3}<0$ and $\omega<0 . \mu 0 \mathrm{t}$ error term of the dynamic model normally distributed as $\left(0,{ }^{2}\right)$.

In above three dynamic models; $\beta$ 's, $\delta$ 's and $\lambda$ 's are short run coefficients of variables in each model. $\Pi_{1}, \Pi_{2}$ and $\Pi_{3}$ are coefficients of ECMt- 1 of all four models respectively. $\phi, \theta$, and $\omega$ are coefficient of shock dummies. Here is the description of econometric techniques that we will use in this study for our findings, i.e. three step methods.

Step I: Unit root test is important for cointegration analysis. To check the order of integration for variables whether they are stationary $\mathrm{I}(0)$ or non-stationary $\mathrm{I}(1)$ for analysis of Johansen cointegration as all variables should be non-stationary at same order for example integrated of order one I(1).

Dickey and Fuller [32] give one of the generally used methods known as Augmented Dickey Fuller (ADF) test of identifying the order of integration $\mathrm{I}(\mathrm{d})$ of variables whether the time series data are stationary or not. Equation (6.8) is the general form of Augmented Dickey Fuller test that will be used to check the stationary of series.

$$
\Delta X_{t}=\alpha+\beta t+\phi X_{t-1}+\theta_{1} \Delta X_{t-1}+\theta_{2} \Delta X_{t-2} \ldots . . \theta_{p} \Delta X_{t-p}+\varepsilon_{t}
$$

Where, Xt denotes the time series variable to be tested, used in model. $\mathrm{t}$ is time period, $\Delta$ is first difference and $\varphi$ is root of equation. $\beta \mathrm{t}$ is deterministic time trend of the series and $\alpha$ denotes intercept. The numbers of augmented lags (p) determined by the dropping the last lag until we get significant lag. The Augmented Dickey Fuller unit root concept is illustrated through equation $\Delta \mathrm{X}_{\mathrm{t}}=(\rho-1) \mathrm{X}_{\mathrm{t}-1}+\varepsilon_{\mathrm{t}}$, Where, ( $\rho-1)$ can be equal to $\varphi$, if $\rho=1$ so series has the unit root, so root of equation is $\varphi=0$.

Step II: If combination of two non-stationary variables generates linear combination, so they called cointegrated. So Johansen [24] presented the Maximum Likelihood Method for estimating the more than one cointegration vector. But for this test all variables sho uld have same order of integration I (d) i.e. I (1).

The method of Maximum Likelihood estimation will be used to estimate our long run coefficients and find the order of cointegration using two test statistics Maximum Eigenvalue test and Trace test.

Step III: The dynamic models of sectoral oil consumption of Pakistan have explained above, will be estimated through ordinary least square (OLS) method.

Estimating the above models, for getting the reliable results our 
model should be well specified and should fulfill all assumptions i.e. OLS statistical assumptions, otherwise our results could be spurious or misleading. Residual of any model is diagnosed for serial correlation through Breusch Godfrey LM test, to check the hetroscadasticity Breusch Pagan will be applied. For testing the normality of the residual of the model Jarque Bera test will be applied. Cumulative sum (CUSUM) and cumulative sum (CUSUM) of square test will be used to check the stability of the mean and variance stability with in the model respectively. For examine the how well our data is good fitted and independent variable are explained by dependent variable R2 and adjusted $\mathrm{R}$ square value is tested.

For the estimation of above model we need data on variables. Five macroeconomic variables have taken for analysis by studying the previous literature. Annual data has taken for all variables since 1972 to 2011. These are related to Pakistan economy. The data is in real format means inflation factor has excluded from it. Data for GDP, Gross Fixed Capital Formation (K) and Labor force (L) has taken from federal bureau of statistics, total oil consumption (TOC) data taken from hydrocarbon institute of Pakistan (HDIP) ministry of petroleum and Oil prices $(\mathrm{P})$ data taken from the monthly statistical bulletins of Pakistan. This data is converted into annual data by taking averages of monthly data.

\section{Results and Discussion}

All data has been transformed into logarithm form. Augmented Dickey Fuller test has applied on the all seven variables. Before applying the ADF test, graphs of series has drawn to examine the pattern of series. By drawing the graphs of series it is noticed that there is trend in the series, so the time trend will be included in the model. Intercept is also included in the model because by examining the figures of series it can be noticed that data doesn't fluctuate around the zero mean. The average of sample is also not zero so that's why intercept will be included. These are only assumptions to check that these are true or not in other words data is stationary or non- stationary (Table 1).

First, the equation of ADF (with drift and time trend in the model) has estimated, for all the variables. At first, unit root has tested at level or without differencing the data. For oil prices, transport and power sector oil consumption lags are taken to remove the problem of serial

\begin{tabular}{|l|l|c|c|c|}
\hline $\begin{array}{l}\text { Variable } \\
\text { LY }\end{array}$ & $\begin{array}{l}\text { Deterministic } \\
\text { Intercept }\end{array}$ & $\begin{array}{c}\text { Lags } \\
\mathbf{0}\end{array}$ & $\begin{array}{c}\text { ADF tau-stat } \\
-\mathbf{2 . 4 8}\end{array}$ & $\begin{array}{c}\text { Outcome } \\
\text { I(1) }\end{array}$ \\
\hline LK & Intercept & 0 & -2.05 & $\mathrm{I}(1)$ \\
\hline LL & Intercept and trend & 0 & -1.58 & $\mathrm{I}(1)$ \\
\hline LP & Intercept and trend & 0 & -2.47 & $\mathrm{I}(1)$ \\
\hline LTRANS & none & 1 & -1.84 & $\mathrm{I}(1)$ \\
\hline LIND & Intercept & 0 & -1.52 & $\mathrm{I}(1)$ \\
\hline LPWG & Intercept and trend & 1 & -2.67 & $\mathrm{I}(1)$ \\
\hline First Difference & & & & \\
\hline Variable & Deterministic & Lags & ADF tau-stat & Outcome \\
\hline$\Delta$ LY & Intercept & 0 & -4.40 & $\mathrm{I}(0)$ \\
\hline$\Delta$ LK & Intercept & 0 & -3.99 & $\mathrm{I}(0)$ \\
\hline$\Delta$ LL & Intercept & 0 & -6.48 & $\mathrm{I}(0)$ \\
\hline$\Delta$ LP & Intercept & 1 & -5.96 & $\mathrm{I}(0)$ \\
\hline$\Delta$ LTRANS & Intercept and trend & 0 & -5.34 & $\mathrm{I}(0)$ \\
\hline$\Delta$ LIND & None & 0 & -4.00 & $\mathrm{I}(0)$ \\
\hline$\Delta$ LPWG & None & 0 & -4.32 & $\mathrm{I}(0)$ \\
\hline
\end{tabular}

Table 1: Unit Root Test of Augmented Dickey Fuller (Annual Data $(T=40)$ ).

\begin{tabular}{|l|l|l|l|l|l|l|}
\hline Lag & LogL & LR & FPE & AIC & SC & HQ \\
\hline 0 & 335.601 & NA & $5.51 \mathrm{E}-14$ & -16.34742 & -15.27006 & -15.9641 \\
\hline 1 & 558.3949 & $328.3279^{*}$ & $1.76 \mathrm{e}-18^{*}$ & -26.75763 & $-24.60291^{*}$ & $-25.99099^{*}$ \\
\hline 2 & 586.4589 & 33.9722 & $1.76 \mathrm{E}-18$ & $-26.91889^{*}$ & -23.68681 & -25.76894 \\
\hline
\end{tabular}

*indicates significant lag at $5 \%$ level.

Table 2: VAR Lag Order Selection for TRANP and Growth.

\begin{tabular}{|c|c|c|c|c|}
\hline \multicolumn{3}{|c|}{ Hypothesis } & Test statistics & Critical values \\
\hline \multirow{6}{*}{$(\lambda$ trace $)$} & $\mathrm{H}_{0}$ & $\mathbf{H}_{\mathbf{a}}$ & & $5 \%$ \\
\hline & $r=0$ & $r \geq 1$ & $101.0587^{*}$ & 69.81889 \\
\hline & $r \leq 1$ & $r \geq 2$ & $50.68022^{*}$ & 47.85613 \\
\hline & $r \leq 2$ & $r \geq 3$ & 18.78234 & 29.79707 \\
\hline & $r \leq 3$ & $r \geq 4$ & 2.892517 & 15.49471 \\
\hline & $r \leq 4$ & $r \geq 5$ & 0.716806 & 3.841466 \\
\hline \multirow[t]{5}{*}{$(\lambda \max )$} & $r=0$ & $r=1$ & $50.37852^{*}$ & 33.87687 \\
\hline & $r \leq 1$ & $r=2$ & $31.89788^{*}$ & 27.58434 \\
\hline & $r \leq 2$ & $r=3$ & 15.88982 & 21.13162 \\
\hline & $r \leq 3$ & $r=4$ & 2.175711 & 14.26460 \\
\hline & $r \leq 4$ & $r=5$ & 0.716806 & 3.841466 \\
\hline
\end{tabular}

*indicates significant at $5 \%$

Table 3: Trace and Max Eigenvalue Test of Cointegration for TRANP and Growth.

correlation so Dickey Fuller test become Augmented Dickey Fuller test, otherwise it is Dickey Fuller test. It can be seen from the table that at level, variables are not stationary. So LY, LL, LP, LK LPWG, LTRANP and LIND are stationary at first difference. Therefore, all variables are integrated of order one, I (1).

\section{Dynamic analysis for transport oil consumption and growth}

Cointegrating analysis: For applying the Johansen cointegration test on first model that includes transport oil consumption in Pakistan. The VAR model has estimated with five variables (LY, LP, LTRANP, LL and LK) and two exogenous pulse dummies and one step dummy of 2005. 1979 dummy is added for capture the effect of Iranian oil revolution, 2008 for global financial crisis and 2005 for oil prices increase up to $\$ 50$ per barrel due to decline in the supply of oil from Iraq and great earth quack in Pakistan. Both dummies influence significantly [33].

Results Lag length selection criteria are given in the Table 2. We can see in the Table 2 that, LR, FPE, SC and HQ criteria indicate the first lag for estimating the VAR at $5 \%$. When the significant lag is selected the VAR model has estimated with one lag. In the model we include the unrestricted trend and intercept in the model. Trend in the data but have no trends in cointegration regression. As discussed in the Johansen [34,35], Johansen and Juselius [34] five different choices of intercept and trend (Table 2).

Long run relationship between the variables has been examined through the two test statistics, Trace test and Maximum Eigenvalue test given by Maximum Likelihood Method. These results are given in the Table 3. According to the Trace test statistics the null hypotheses $\mathrm{r}=0$ and $\mathrm{r} \leq 1$ is rejected at $5 \%$ against the alternative hypotheses $\mathrm{r} \geq$ land $\mathrm{r} \leq 2$. Through the Maximum Eigenvalue test statistics the null hypotheses $r=0$ and $r \leq 1$ is rejected at $5 \%$ against the alternative hypotheses $r=1$ and $r=2$ (Table 3 ).

Both test statistics indicates two log run cointegrating relationships within the variables for this model. But in this study we take only one cointegrating vector for further analysis. 
Now we estimate the cointegration relationship by using Maximum Likelihood Method. Normalized coefficients are given below in equation (7.1). (Chi square values are in parenthesis.)

$$
\mathrm{LY}_{\mathrm{t}}=-4.47 \mathrm{LK}_{\mathrm{t}}+14.33 \mathrm{LL}_{\mathrm{t}}+3.96 \mathrm{LTRANP}_{\mathrm{t}}-4.38 \mathrm{LP}_{\mathrm{t}}
$$

Oil consumption in transport sector is major part of total oil consumption Pakistan. Almost $49 \%$ of total oil consumption has used by the transport sector in 2011. Observing the above normalize long run equation (7.1) labor force shows significantly positive impact on the GDP of Pakistan as expected but capital stock shows negative impact on GDP. Negative relationship is due to inefficient investment in different sectors of economy also due to shortage of capital stock to influence positively on GDP. The oil price shows significant negative impact on GDP, showing $4.38 \%$ negative change in the GDP due to one percent change in the oil prices. Due to circular debt problem created by the oil creates negative impact on economic growth. Pakistan's imports mostly comprising on the petroleum or petroleum products. So the oil is the costly input product and impacted the economic growth. In previous years of Pakistan the oil consumption especially in transport sector growth has decreased almost $0.97 \%$. The consumption of oil is not efficient in the Pakistan so it allocates the negative impact on the overall economy or GDP.

There is positive relationship between the GDP and transport oil consumption in long run, there is $3.96 \%$ change in the GDP due to one percent positive change in the transport oil consumption. These results satisfy the theory having positive relationship between GDP and consumption.

Short run dynamic results: Parsimonious Error Correction Model (7.2) for transport oil consumption and growth has estimated through general to specific approach at lag one selected on the basis of diagnostic tests. ( $\mathrm{t}$-statistics values in parenthesis)

$\Delta \mathrm{LY}_{\mathrm{t}}=0.07-0.003_{\mathrm{t}}-0.36 \Delta \mathrm{LY}_{\mathrm{t}-1}+0.18 \Delta \mathrm{LK}_{\mathrm{t}}-0.47 \Delta \mathrm{LL}_{\mathrm{t}-1}+$ $0.16 \Delta$ LTRANP $_{\mathrm{t}}-$

$$
\begin{aligned}
& (5.90)(-2.74) \quad(-2.20) \quad(4.09) \quad(-2.79) \\
& 0.02 \mathrm{D}_{1981}+0.02 \mathrm{D}_{1988}+0.004 \mathrm{D}_{2005}-0.02 \mathrm{ECM}_{\mathrm{t}-1} \\
& (2.88) \quad(3.19) \quad(4.32)
\end{aligned}
$$

\section{Diagnostic tests:}

$\mathrm{R}^{2}=0.63$,

$$
\bar{R}^{2}=0.51
$$

Breusch Godfrey LM test of Autocorrelation $\mathrm{F}_{(1,27)}=0.02(0.86)$,

Jarque Bera test of Normality $\chi_{(2)}=0.81(0.66)$,

Breusch Pagan Godfrey Hetroscadasticity test $\mathrm{F}_{(9,28)}=0.86(0.56)$,

Diagnostic tests of first dynamic model (5.2) are identified here, first by proving the no serial correlation through LM test. The value of F statistics is 0.02 so we cannot reject the null hypotheses of no serial correlation. The chi square $\chi^{2}$ value of Jarque Bera is 0.81 tells that residual follow the normal distribution as we cannot reject the null of hypothesis and also the residual have equal spread of variance by examining the F statistics of hetroscadasticity test that is 0.86 . The $\mathrm{R}^{2}$ and adjusted $\bar{R}^{2}$ shows that independent variables are explained $63 \%$ and $51 \%$ by dependent variable respectively.

Above Figures 4 and 5 for CUSUM and CUSUM of squares, Browne et al. are given, that indicates stability mean and variance of

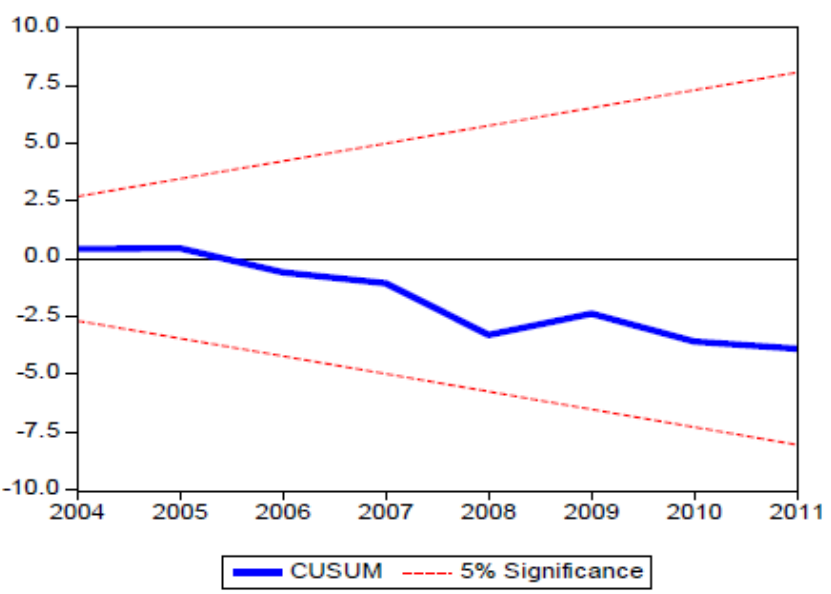

Figure 4: CUSUM Test of Mean Stability for TRANP and Growth.

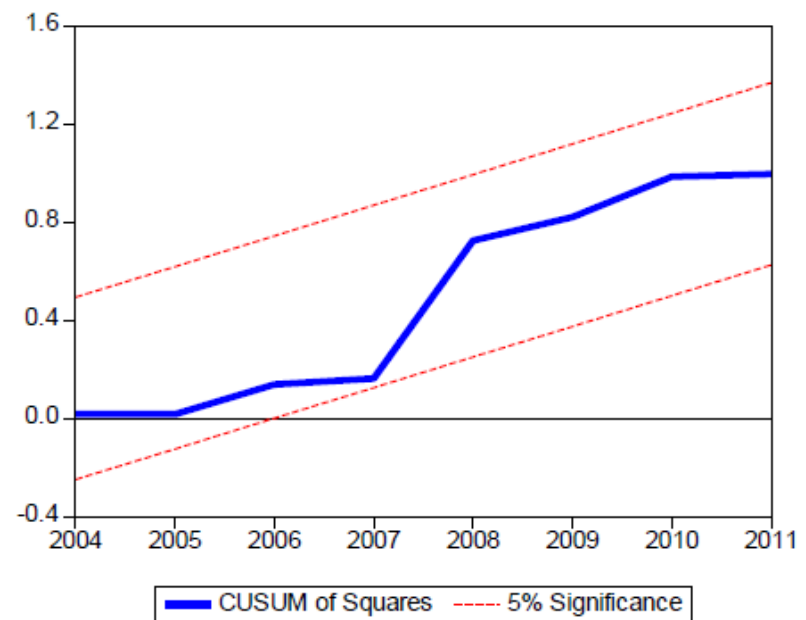

Figure 5: CUSUM of square Test of Variance Stability for TRANP and Growth.

parameters of model respectively, as line lies between the significant bound at $5 \%$ level.

However, by examining the dynamic model it can be noticed that, the magnitude of $\mathrm{ECM}_{\mathrm{t}-1}$ is negative and significant according to theory, in equation (7.2). The value shows the error is adjusting with the speed of $0.02 \%$ in the one year. We can see that the speed of adjustment is very slow to word equilibrium. The significance of this term ratifies the long run relationship between variables.

According to equation (7.2) the coefficient of change in current capital stock is positively impacting on the economic growth as expected. The value of change in first lagged labor shows negative relationship with economic growth as explained in above model that labor force is not efficient. The magnitude of change in current transport oil consumption shows positive impact on economic growth in short run. If there is one percent change in the current transport oil consumption there will be $0.16 \%$ change in the economic growth. In 1981 oil prices increases internationally, due to invasion of Afghanistan that's why lots of investment plans remained uncompleted and also 
Citation: Nazir S, Hameed T (2015) Impact of Oil Price and Shocks on Economic Growth of Pakistan: Multivariate Analysis (Sectoral Oil Consumption) Bus Eco J 6: 182. doi:10.4172/2151-6219.1000182

Page 7 of 11

due to Supply of oil from Iraq decline caused by Iran-Iraq war. In the start of 2005 the Pakistan economy was in its better condition due to increased growth of GDP in 2004, the oil prices were also stable in these years so it has positive impact on the economic growth of Pakistan and comparatively very low impact, international oil shock in 2005 has not affected the Pakistan economy. In 1988 the production and discoveries in the oil sector of Pakistan increased in this era, also average growth was $5.8 \%$. So it has positive significant influence on the economic growth.

It is concluded from above discussion of dynamic model, that transport oil consumption has positive impact on GDP in long run and short run. Oil price has negative relationship between GDP in long run but there is no impact on growth in short run. Shock dummies have significant positive impact on the growth except one has significant negative impact but these shocks have very minute impact on the Pakistan economic growth.

\section{Dynamic analysis for power sector oil consumption and growth}

Cointegrating analysis: For applying the Johansen cointegration test on second model that includes power sector oil consumption in Pakistan. There is need to set the VAR first so the VAR model has estimated with five variables (LY, LP, LPWG, LL and LK) and two exogenous pulse dummies , these dummies has significant contribution in the VAR model, 1979 and 2008 dummies has explained already in above discussion.

Lag length tests has been used to identify the optimal lag. The results are given in the Table 4. As it we can examine through the Table 4, LR, FPE, SC and HQ criteria indicates the two lags for estimating the VAR at $5 \%$. When the significant lag is selected the VAR model has estimated with two lags. In the model we also include the unrestricted trend and intercept in the model. Trends in the data but have no trends in cointegration regression. As discussed in the Johansen [34,35], Johansen and Juselius [34] five different choices of intercept and trend (Table 4).

Cointegrating relationship has examined between the variables, through the two test statistics, Trace test and Maximum Eigenvalue test proposed by the Maximum Likelihood Method of Johansen [24]. These results are given in the Table 5. According to the Trace test statistics the null hypotheses $r=0$ and $r \leq 1$ is rejected at $5 \%$ against alternative hypotheses $r \geq 1$ and $r \leq 2$. Through the Maximum Eigenvalue test statistics the null hypotheses $r=0$ and $r \leq 1$ is rejected at $5 \%$ against the alternative hypotheses $r=1$ and $r=2$. Both test statistics indicates two cointegrating vector or there are two log run cointegrating relationships in the variables. But in this study we take only one cointegrating vector for further analysis (Table 5).

Now the long run relationship has been examined through Johansen Maximum Likelihood Method. From here we can move forward to take cointegrating estimates and short run dynamics analysis of our model that is given below in equation 5.3. (Chi square values are in parenthesis).

\begin{tabular}{|c|c|c|c|c|c|c|}
\hline Lag & LogL & LR & FPE & AIC & SC & HQ \\
\hline 0 & 257.7832 & NA & $3.31 \mathrm{E}-12$ & -12.25175 & -11.17439 & -11.86843 \\
\hline 1 & 484.9878 & 334.8278 & $8.36 \mathrm{E}-17$ & -22.8941 & $-20.73938^{*}$ & -22.12746 \\
\hline 2 & 517.3863 & $39.21921^{*}$ & $6.67 \mathrm{e}-17^{*}$ & $-23.28349^{*}$ & -20.05141 & $-22.13354^{*}$ \\
\hline
\end{tabular}

*indicates significant lag at $5 \%$ level.

Table 4: VAR Lag Order Selection for PWG and Growth.

\begin{tabular}{|c|c|c|c|c|}
\hline & \multicolumn{2}{|c|}{ Hypothesis } & \multirow[t]{2}{*}{ Test statistics } & \multirow{2}{*}{$\begin{array}{c}\text { Critical values } \\
5 \%\end{array}$} \\
\hline \multirow{6}{*}{ ( $\lambda$ trace $)$} & Ho & $\mathrm{Ha}$ & & \\
\hline & $r=0$ & $r \geq 1$ & $110.3783^{*}$ & 69.81889 \\
\hline & $r \leq 1$ & $r \geq 2$ & $59.87456^{*}$ & 47.85613 \\
\hline & $r \leq 2$ & $r \geq 3$ & 26.57852 & 29.79707 \\
\hline & $r \leq 3$ & $r \geq 4$ & 6.688208 & 15.49471 \\
\hline & $r \leq 4$ & $r \geq 5$ & 0.254841 & 3.841466 \\
\hline \multirow[t]{5}{*}{$(\lambda$ max $)$} & $r=0$ & $r=1$ & $50.50379^{*}$ & 33.87687 \\
\hline & $r \leq 1$ & $r=2$ & $33.29604^{*}$ & 27.58434 \\
\hline & $r \leq 2$ & $r=3$ & 19.89031 & 21.13162 \\
\hline & $r \leq 3$ & $r=4$ & 6.433367 & 14.26460 \\
\hline & $r \leq 4$ & $r=5$ & 0.254841 & 3.841466 \\
\hline
\end{tabular}

*indicates significant at $5 \%$.

Table 5: Trace and Max Eigenvalue Test of Cointegration for PWG and Growth.

$$
\mathrm{LY}_{\mathrm{t}}=-2.10 \mathrm{LL}_{\mathrm{t}}-1.62 \mathrm{LP}+0.22 \mathrm{LPWG}_{\mathrm{t}}+2.25 \mathrm{LK}_{\mathrm{t}}
$$
(19.44)
(36.48)
(27.14)
(74.47)

In long run equation (7.3) for power sector oil consumption and growth the capital stock shows significant positive impact on the GDP of Pakistan as expected but labor force shows negative relationship with GDP because in Pakistan labor force is not so efficient nor productive to impact GDP positively. The coefficient of oil prices has significant negative influence on the GDP. If there is one percent increase in the oil prices there will be $1.62 \%$ decrease in the GDP. The reason of negative relationship has explained above in detail. We can say that increase in the oil prices in the energy sector cause increase in the electric bills, petrol prices, increase the tax and also increase in the circular debt, which has throws bad impact on economic growth. The coefficient of power generation oil consumption shows positive impact on the GDP. If there is one percent increase in the power sector oil consumption there will be $0.22 \%$ increase in the GDP. So oil consumption in this sector is important determinant to influence the economic growth positively in long run.

Short run dynamics results: Short run dynamic model given in equation (7.4) for power sector oil consumption and growth is evaluated through the general to specific approach [36] estimated with two lags selected on the basis of diagnostic tests. (t-statistics are in parenthesis)

$$
\begin{aligned}
& \Delta \mathrm{LY}_{\mathrm{t}}=0.08-0.001_{\mathrm{t}}-0.23 \Delta \mathrm{LY}_{\mathrm{t}-1}+0.13 \Delta \mathrm{LK}_{\mathrm{t}-2}-0.28 \Delta \mathrm{LL}-0.22 \Delta \mathrm{LL}_{\mathrm{t}-1}+ \\
& \begin{array}{llll}
(4.92) & (-8.41) \quad(-2.16) \quad(4.18)
\end{array}
\end{aligned}
$$

\section{Diagnostic tests}

$\mathrm{R} 2=0.95, \quad \bar{R}^{2}=0.89$

Breusch Godfrey LM test of Autocorrelation $\mathrm{F}_{(1,15)}=0.81(0.38)$,

Jarque Bera test of Normality $\chi_{(2)}=5.43(0.06)$,

Breusch Pagan Godfrey Hetroscadasticity Test $\mathrm{F}_{(20,16)}=0.78(0.70)$,

Diagnostic tests of dynamic model (7.4) are demonstrated here, first by examining the serial correlation through LM test. The value of 
F statistics is 0.81 so we cannot reject the null hypotheses of no serial correlation. The chi square $\chi^{2}$ amount of Jarque Bera is 5.43 tells that residual follow the normal distribution as we cannot reject the null of hypothesis and also the residual have equal spread of variance by observing the F statistics of hetroscadasticity test that is 0.78 . The $\mathrm{R}^{2}$ and adjusted shows that independent variables are explained $95 \%$ and $89 \%$ by dependent variable respectively. For testing the stability of the mean and variance of parameters of model, CUSUM and CUSUM of squared are plotted respectively. Through Figures 6 and 7 it can be noted that calculated lines are within the significance bounds of $5 \%$. So the model is stable in mean and variance (Figures 6 and 7). Now the model is well specified for explanation of dynamic relationship.

The value of $\mathrm{ECM}_{\mathrm{t}-1}$ is negative and significant to theory. The value in equation (7.4) indicates the error is correcting with the speed of $0.02 \%$ in the one year. The significance of this term also approves the long run relationship between variables.

The coefficient of change in current capital stock in equation (7.4) is positively influence on the economic growth as expected. The value of change in current and first lagged labor shows negative relationship with growth as explained in above model that labor force is not efficient. The magnitude of change in current power sector oil consumption shows positive impact on growth in short run. If there is one percent

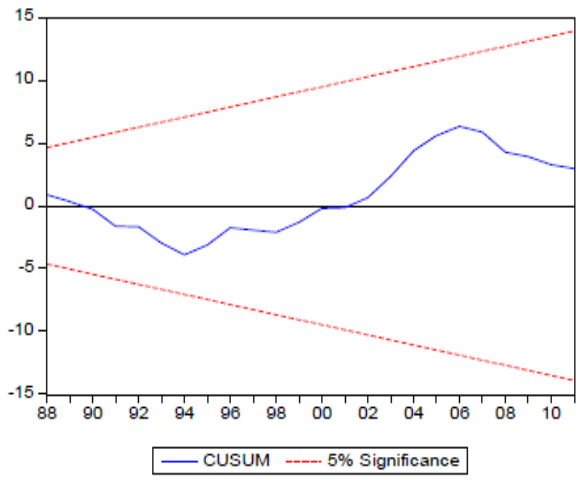

Test of Mean

Figure 6: CUSUM Test of Mean Stability for PWG.

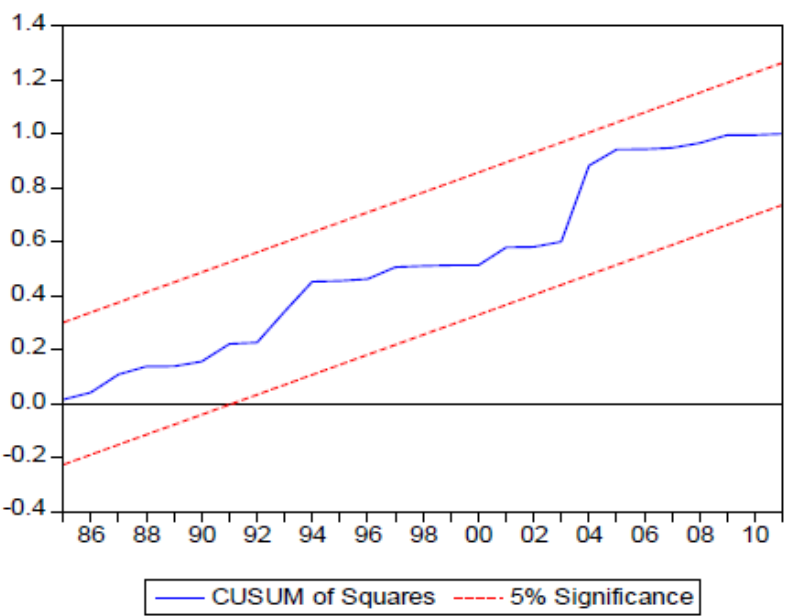

Figure 7: CUSUM of Square Test of Variance Stability for PWG and Growth. change in the power sector oil consumption there will be $0.01 \%$ change in the GDP. But the change in lagged value of power sector oil consumption shows negative relationship with growth. It could be the reason of energy is treated as intermediate good in the previous year. The negative impact could be the alternative use of energy product like cheaper gas consumption. If there is one percent change in the current and lagged oil price there will be 0.05 and $0.01 \%$ change in the growth. According to Rasmussen and Roitman [37], 125 importing countries including Pakistan shows positive impact of oil prices on the GDP. If there is one percent increase in the change of current and lagged oil pr ice there will be 0.10 and 0.13 percent increase in the economic growth. So increase in the prices some time takes as good time in the economy, as increase in oil prices generally appears to be demand driven [37-40]. Also study of Akram [11] shows positive significant relation between oil price increase and growth in case of Pakistan. Dummy has positive impact on the growth of Pakistan however in 1979 there was second big oil shock in world. Dummy 2005 added due to increase of oil prices internationally due to destruction of Hurricane Katrina and decline in Iraq's oil supply and the great earth quack has badly impacted on all sectors of the economy and in 2007 the global financial crisis cause to increase in oil prices that have negative influence on the growth of Pakistan.

So finally it can be said that, power sector oil consumption effect positively to GDP in long run and also in short run. Oil price has negative relationship with GDP in long run and positive in short run. Oil Shock dummies variables also have significant impact on Pakistan economic growth [41-44].

\section{Dynamic analysis for industrial oil consumption and growth}

Cointegrating analysis: For applying the Johansen cointegration test on third model that includes industrial oil consumption in Pakistan. There is need to set the VAR first so the VAR model has estimated with five variables (LY, LP, LIND, LL and LK) and two exogenous pulse dummies. Dummy is added that have significant exogenous impact in the given VAR system, increase in oil prices up to $\$ 40$ in last quarter of 2004 and reaches at $\$ 50$ per barrel in 2005 due to the destruction of hurricane Katrina and decline in the supply of Iraq's oil production. As Iraq contain large oil reserve. Dummy capturing the effect of second oil prices shock that led from 1979 to 1981, in 1981 there was decline in the oil supply from middle east and oil glut of 1981 due to decrease in oil consumption due to its high price [33,45-47]. Lag length selection criteria such as; LogL, LR, FEP, AIC, SC, HQ has been used to select the optimal lag. The results are given below in the Table 6 . We can see that, According to the Table $6 \mathrm{LR}, \mathrm{FPE}$ and AIC criteria indicates the two lags for estimating the VAR at $5 \%$. When the significant lag is selected the VAR model has estimated with two lags (Table 6).

In the model we also include the unrestricted trend and intercept in the model same as previous model. Trends in the data but have no trends in cointegration regression. As discussed in the Johansen $[34,35,48]$ and Johansen and Juselius [34,49] five different choices of intercept and trend. Cointegrating relationship has examined the two test statistics, Trace test and Maximum Eigenvalue test calculated

\begin{tabular}{|l|l|l|l|l|l|l|}
\hline Lag & LogL & LR & FPE & AIC & SC & HQ \\
\hline 0 & 267.9786 & NA & $1.14 \mathrm{E}-12$ & -13.31466 & -12.66825 & 13.08467 \\
\hline 1 & 501.6226 & 368.9116 & $1.99 \mathrm{E}-17$ & -24.29593 & $-22.57215^{*}$ & $-23.68262^{*}$ \\
\hline 2 & 532.2705 & $0.32621^{*}$ & $1.66 \mathrm{e}-17^{*}$ & $24.59319^{*}$ & -21.79205 & -23.59656 \\
\hline
\end{tabular}

*indicates significant lag at $5 \%$ level.

Table 6: VAR Lag Order Selection for IND and Growth. 
Citation: Nazir S, Hameed T (2015) Impact of Oil Price and Shocks on Economic Growth of Pakistan: Multivariate Analysis (Sectoral Oil Consumption). Bus Eco J 6: 182. doi:10.4172/2151-6219.1000182

Page 9 of 11

\begin{tabular}{|c|c|c|c|c|}
\hline \multicolumn{3}{|c|}{ Hypothesis } & \multirow{2}{*}{$\begin{array}{c}\text { test } \\
\text { statistics }\end{array}$} & \multirow{2}{*}{$\begin{array}{c}\text { Critical values } \\
5 \%\end{array}$} \\
\hline \multirow{6}{*}{ ( $\lambda$ trace) } & Ho & $\mathrm{Ha}$ & & \\
\hline & $r=0$ & $r \geq 1$ & $103.7253^{*}$ & 69.81889 \\
\hline & $r \leq 1$ & $r \geq 2$ & $52.30240^{*}$ & 47.85613 \\
\hline & $r \leq 2$ & $r \geq 3$ & 17.70686 & 29.79707 \\
\hline & $r \leq 3$ & $r \geq 4$ & 7.306180 & 15.49471 \\
\hline & $r \leq 4$ & $r \geq 5$ & 1.392491 & 3.841466 \\
\hline \multirow[t]{5}{*}{ ( $(\lambda$ max $)$} & $r=0$ & $r=1$ & $51.42288^{*}$ & 33.87687 \\
\hline & $r \leq 1$ & $r=2$ & $34.59554^{*}$ & 27.58434 \\
\hline & $r \leq 2$ & $r=3$ & 10.40068 & 21.13162 \\
\hline & $r \leq 3$ & $r=4$ & 5.913689 & 14.26460 \\
\hline & $r \leq 4$ & $r=5$ & 1.392491 & 3.841466 \\
\hline
\end{tabular}

*indicates significant at $5 \%$

Table 7: Trace and Max Eigenvalue Test of Cointegration for IND and Growth.

through the Maximum Likelihood Method by Johansen. These results are given in the Table 7 . According to the Trace test statistics the null hypotheses $r=0$ and $r \leq 1$ is rejected at $5 \%$ against alternative hypotheses $r \geq 1$ and $r \leq 2$. Through the Maximum Eigenvalue test statistics the null hypotheses $r=0$ and $r \leq 1$ is rejected at $5 \%$ against the alternative hypotheses $r=1$ and $r=2$. Both test statistics indicates two cointegrating vector or there are two long run cointegrating relationships in the variables for this model. But in this study we take only one cointegrating vector for further analysis (Table 7).

Now will estimate the of long run coefficients of power sector and growth model by using Maximum Likelihood Method (Chi square values are in parenthesis)

$$
\mathrm{LY}_{\mathrm{t}}=0.20 \mathrm{LIND}_{\mathrm{t}}+5.83 \mathrm{LL}_{\mathrm{t}}-2.46 \mathrm{LP}_{\mathrm{t}}-1.16 \mathrm{LK}_{\mathrm{t}}
$$

$$
\begin{array}{llll}
(9.42) \quad(102.01) \quad(62.56) \quad(18.31)
\end{array}
$$

The normalized long run equation (7.5) given above whose estimates are given by adding the sectoral oil consumption of industrial sector. The labor force variables shows significant positive impact on the GDP as expected. The capital stock shows negative impact on GDP, if here is one percent increase in the capital stock there will be $1.16 \%$ decrease in the GDP. Negative relationship is due to inefficient investment in different sectors of economy also due to shortage of capital stock to influence positively on GDP. The oil price shows negative relationship with GDP. As explained above in the model. Higher oil prices have bad impact on the economy due to its cost. The industrial oil consumption indicated positive long run relationship with GDP. The posit ive relationship has explained above, such as oil consumption in industrial sector for different needs enhance the growth of the industry and overall economy. We know oil is becoming basic need in production sector. So if there is $1 \%$ increase in industrial oil consumption there will be $0.20 \%$ increase in the GDP.

Short run dynamic results: Now the Error Correction Model has estimated for industrial oil consumption and growth, it is estimated through general to specific approach $[36,50]$ at second lag selected on the basis of diagnostic tests illustrated below equation (7.6). (T-statistics are given in parenthesis)

$\Delta \mathrm{LY}_{\mathrm{t}}=0.19+0.17 \Delta \mathrm{LK}_{\mathrm{t}-2}-0.30 \Delta \mathrm{LL}_{\mathrm{t}-1}+0.49 \mathrm{~L} \Delta \mathrm{L}_{\mathrm{t}-2}+0.10 \Delta \mathrm{LP}_{\mathrm{t}}+$ $0.12 \Delta \mathrm{LP}_{\mathrm{t}-2}$

(5.32) (3.40) (-2.23) (3.48) (2.83)(3.58)

$$
0.01 \mathrm{D}_{1979}+0.02 \mathrm{D}_{1988}-0.04 \mathrm{D}_{2008}-0.01 \mathrm{D}_{2005}-0.01 \mathrm{ECT}_{\mathrm{t}-1}
$$
$(-2.85)$
(3.85)
$(-5.00)$
$(-3.13)$

$(-4.96)$

\section{Diagnostic tests:}

$$
\mathrm{R}^{2}=0.73 \quad \bar{R}^{2}=0.62
$$

Breusch Godfrey LM test of Autocorrelation $\mathrm{F}_{(1,24)}=0.02(0.88)$,

Jarque Bera test of Normality $\chi_{(2)}^{2}=0.69(0.70)$,

Breusch Pagan Godfrey Hetroscadasticity Test $\mathrm{F}_{(11,25)}=0.62(0.78)$,

Diagnostics of third dynamic model (7.6) are described here, mainly by checking the serial correlation through LM test. The value of F statistics is 0.02 so we cannot reject the null hypotheses of no serial correlation. The chi square $\chi^{2}$ value of Jarque Bera is 0.62 tells that residual follow the normal distribut ion as we can cot reject the null of hypothesis and also the residual have equal spread of variance by examining the $\mathrm{F}$ statistics through Breusch-Pagan $-{ }_{2}$ Godfrey test of hetroscadasticity that is 0.62 . The $\mathrm{R}^{2}$ and adjusted $R^{2}$ shows that independent variables are explained $73 \%$ and $62 \%$ by dependent variable respectively (Figures 8 and 9 ).

The cumulative sum (CUSUM) and cumulative of squares test

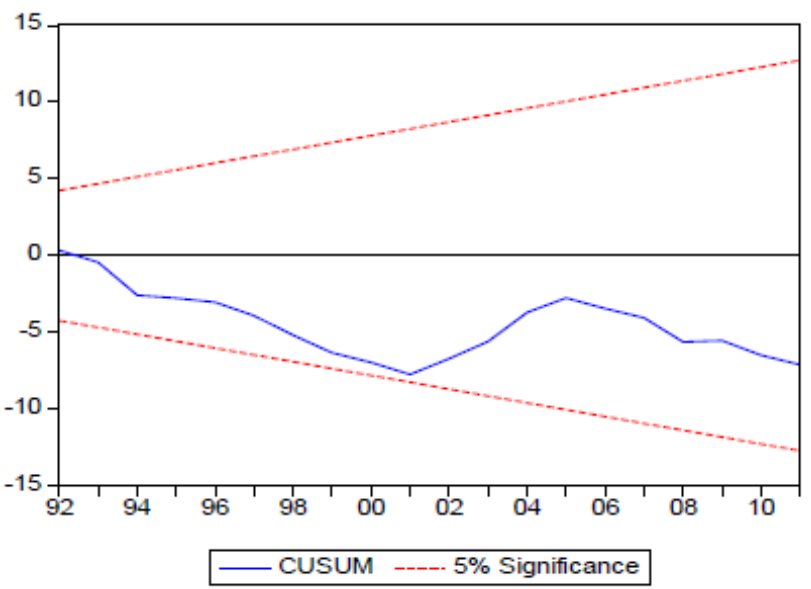

Figure 8: CUSUM Test of Mean Stability for IND and Growth.

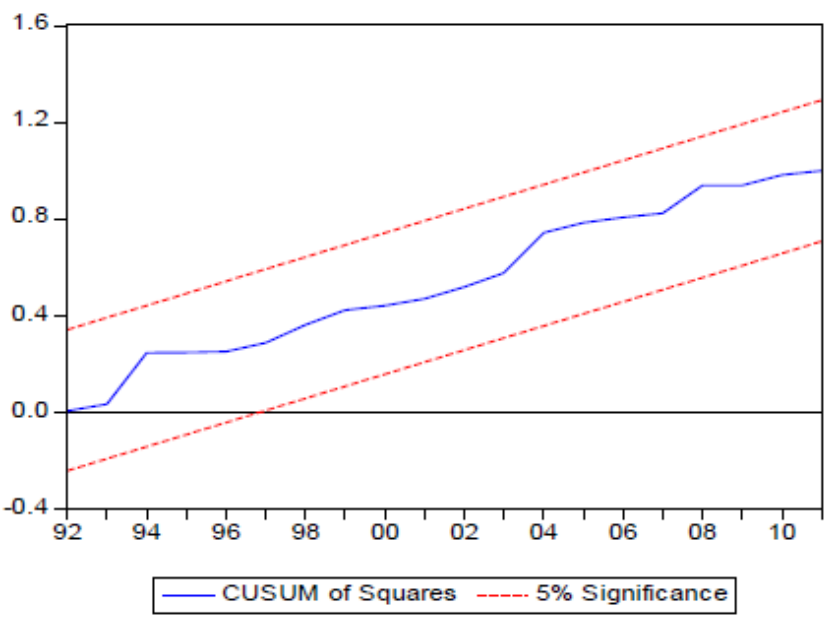

Figure 9: CUSUM of Square Test of Variance Stability for IND and Growth. 
has used to test the constancy of mean and variance of the parameters with in the model respectively through Figures 8 and 9 it can examine that line is between the significant bound so our dynamic model of industrial oil consumption is stable.

Now we move forward for description of dynamic relationship. The magnitude of $\mathrm{ECM}_{\mathrm{t}-1}$ is negative and significant according to theory given in equation (7.6). The value shows the error is correcting with the speed of $0.01 \%$ in the one year. We can see that the speed of adjustment is very slow to word equilibrium. The significance of this term confirms the long run relationship between variables [51-53].

The coefficient of change in lagged capital stock is positively impacting on the economic growth as expected and explained in the first dynamic model. The value of change in first lagged labor shows positive relationship with economic growth as it's according to theory because labor force helps to increase the growth but second lag shows negative impact as explained in previous dynamic equation. The magnitude of change in oil prices in current and lagged period shows positive impact on economic growth in short run. If there is one percent change in the current and lagged oil price there will be 0.10 and 0.12 percent change in the economic growth respectively. The effect of dummies have already described above [54-58].

From the dynamic analysis between industrial oil consumption and growth it is summaries that, there is positive relationship between industrial oil consumption and GDP in long run but IND oil consumption has not influencing in short run to growth. Oil prices negatively related with GDP in long run and positively in short run. Oil shock dummies impacting negatively except one, but these have very less influence on the growth of Pakistan

\section{Conclusion}

Pakistan is facing oil related problems since many years, specifically oil prices and its increasing demand in every sector of economy. So keeping this point of view in this study impact of oil price and shocks on economic growth has been checked including sectorial oil consumption. Time series approach has been used in this study to test the long run and short run dynamics through Johansen approach of co integration initially ADF test for finding order of integration I (d). Annual data has used since 1972-2011 for analysis. Three models of Cobb- Douglas production function are constructed for three major oil sectors including oil prices depending on GDP. Shocks dummies are also included in these models as previous studies had not concern about the oil shocks in data. In Pakistan only few paper are found related to causal relationship between oil consumption and GDP, in these papers authors has ignored the sectoral use of oil and impact of oil price and shocks specifically Pakistan's oil prices were not taken in any paper for this context, So oil price variable and shock dummies have been added in the analysis. From the analysis finally it can be concluded that oil consumption variables have positive impact on economy in long run and also shows the long run causal relationship from oil consumption variables to GDP also oil price variable shows negative impact as expected. In short run oil consumption variables shows very little impact on economic growth of Pakistan however, shocks dummies also influencing negatively to the growth in short run but with low percentage. In short run consumption as well oil price variables also show causal relation toward growth. So we can say oil consumption is important to enhance the economic growth of Pakistan specifically in long run scenario but less contribution toward economic growth in short run.
If we examine the previous study of Bedi-uz-Zaman et al. [5], that was first study in Pakistan that had investigated the relationship between oil consumption in sectors of Pakistan and economic growth and compare the results of our study it can be seen that by estimating individual dynamic model for each sector give different results up to some context [59]. In previous study oil price variable and shock dummies were not included that have significant impact on the economy. Oil consumption variables are positively cointegrated with economic growth as concluded in previous study. Results of our study are also supports the results of the study of Akram [11] shows positive significant relationship of increase in oil prices for Pakistan [60]. The results are also consistent with the findings of Khan and Qayyum [10] that capital and labor variables have greater impact on economic growth then other variables $[61,62]$.

Additionally, the policy implications could be for this study are, firstly; investing on the labor and capital, we can get fruitful results as these variables shows greater impact on economic growth of Pakistan both in long run and short run. Secondly, the transport oil consumption that is the major sector of oil consumption of Pakistan creating larger impact on economy so there is need to make this sector improved and controls the oil prices impacting negatively in the long run greater than any other sector. Finally, Industrial and power oil consumption are very important part of any economy that could boost up to growth but these sectors need to much planning in prices controlling and developing the safe guards for oil shocks, so that these sector could take part in up grating the economy of Pakistan.

\section{References}

1. Kitasei S, Narotzky N (2011) Global oil market resume growth after stumble in 2009. World watch Institute.

2. Brown S, Yucel M (2002) Energy Prices and Aggregate Economic Activity: An Interpretative Survey. Quarterly Review of Economics and Finance 42: 193-208.

3. Loungani P (1986) Oil Price Shocks and the Dispersion Hypothesis. Review of Economics and Statistics 63: 536-539.

4. Hou Q (2009) The Relationship between Energy Consumption Growth and Economic Growth in China. International Journal of Economic and Finance.

5. Zaman B, Farooq M, Ullah S (2011) Sectoral Oil Consumption and Economic Growth in Pakistan: An ECM Approach. American Journal of Scientific and Industrial Research 2: 149-159.

6. Chontanawat J, Hunt LC, Pierse R (2008) Does Energy Consumption Cause Economic Growth? Evidence from a Systematic Study of Over 100 Countries. Journal of Policy Modeling 30: 209-220.

7. Hamilton JD (1983) Oil and Macroeconomics since World War II. Journal of Political Economy 91: 228-248.

8. Hooker M (1996) What Happened To Oil Price- Macroeconomic Relationship? Journal of Monetary Economics 38: 195-213.

9. Malik A (2010) Oil Prices and Economic Activity in Pakistan. South Asian Economic Journal 11: 223-244.

10. Khan AM, Qayyum A (2007) Dynamic Modeling of Energy and Growth in South Asia. Pakistan Development Review 46: 481-498.

11. Akram M (2012) Do crude oil price changes affect economic growth of India Pakistan and Bangladesh? A multivariate time series analysis. Hogskolan Dalarna

12. Kraft J, Kraft A (1978) On the Relationship between Energy and GNP. Journal of Energy and Development 3: 401-403.

13. Bekhet AH, Yusop MYN (2009) Assessing the Relationship between O Prices, Energy Consumption and Macroeconomic Performance in Malaysia: Cointegration and Vector Error Correction Model. International Business Research.

14. Cheng BS, Lai TW (1997) An Investigation of Cointegration and Causality 
Citation: Nazir S, Hameed T (2015) Impact of Oil Price and Shocks on Economic Growth of Pakistan: Multivariate Analysis (Sectoral Oil Consumption) Bus Eco J 6: 182. doi:10.4172/2151-6219.1000182

Page 11 of 11

Between Energy Consumption and Economic Activity in Taiwan. Energy Economics 19: 435-444.

15. Asafu-Adjaye J (2000) The Relationship between Energy Consumption, Energy Prices and Economic Growth: Time Series Evidence from Asian Developing Countries. Energy Economics 22: 615-625.

16. Lee C, Chang C (2005) Structural Breaks, Energy Consumption, and Economic Growth Revisited: Evidence from Taiwan. Energy Economics 27: 857-872.

17. Siddiqui R (2004) Energy and Economic Growth in Pakistan. The Pakistan Development Review 43: 175-200.

18. Bhusal TP (2010) Econometric Analysis of Oil Consumption and Economic Growth in Nepal. Economic Journal of Development Issues 11 and 12: 135143.

19. Pradhan PR (2010) Energy Consumption- Growth Nexus In SAARC Countries: Using Cointegrating and Error Correction Model. Modern Applied Science.

20. Qazi MAH, Riaz S (2008) Causality between Energy Consumption and Economic Growth: The Case of Pakistan. Lahore Journal of Economics 13: $45-58$

21. Ahmed F (2013) The Effect of Oil Prices on Unemployment: Evidence from Pakistan. Business and Economics Research Journal 4: 43-57.

22. Jawad M (2013) Oil Price Volatility and its Impact on Economic Growth in Pakistan. Journal of Finance and Economics 1: 62-68

23. Kiani A (2011) Impact of High Oil Prices on Pakistan's Economic Growth International Journal of Business and Social Science 2: 209.

24. Johansen S (1988) Statistical Analysis of Cointegrating Vectors. Journal of Economic Dynamics and Control 12: 231-254.

25. Soytas U, Sari R (2003) Energy Consumption and GDP: Causality Relationship in G-7 Countries and Emerging Markets. Energy Economics 25: 33-37.

26. Akarca AT, Long TV (1980) On the Relationship between Energy and GNP: A Reexamination. Journal of Energy Development 5: 326-331.

27. Cobb C, Douglas P (1928) A Theory of Production. An American Economic review 18:139-165.

28. Georgescu-Roegen N (1975) Energy and Economic Myths. Southern Economic Journal 41: 347-81.

29. Georgescu-Roegen N (1977) The Steady State and Ecological Salvation: A Thermodynamic Analysis. Bio Science 27: 266-270.

30. Saibu F (2011) Oil Price, Energy Consumption and Macroeconomic Performance: Further Evidence from Nigeria (1970- 2009). USAEE-IAEE WP $11-091$.

31. Beaudreau BC (2005) Engineering and Economic Growth. Structural Change and Economic Dynamics 16: 211-220.

32. Dickey DA, Fuller WA (1979) Distribution of Estimators for Autoregressive Time Series Regression with a Unit Root. Journal of the American Statistical Association 74: 427-431.

33. Hamilton JD (2011) Historical Oil Shocks. NBER Working paper No. 16790.

34. Johansen S, Juselius K (1990) Maximum Likelihood Estimation and Inference on Co - integration with Applications to the Demand for Money. Oxford Bulletin of Economics and statistics 52: 169-210.

35. Johansen S (1995) Likelihood Based Inference in Cointegrated Vector Autoregressive Models. Oxford: Oxford University Press.

36. Campos J, NR Ericsson, Hendry DF (2005) General to Specific Modelling: an overview and selected bibliography. The Federal Reserve Board.

37. Rasmussen NR, Roitman A (2011) Oil Shocks in a Global Perspective: Are They Really That Bad? IMF.

38. Abid M, Sabri M (2012) Energy Concept-Economic Growth Nexus: Does the Level of Aggregation Matter? International Journal of Energy Economic and Policy 2: 55-62.

39. Ahmed A, Kumar MJ (2008) Status of Petroleum Sector in Pakistan- A Review. Oil and gas business.

40. Alam S, Butt MS (2002) Causality between Energy Consumption and Economic Growth in Pakistan: An Application of Cointegration and Error Correction Modeling Techniques. Pacific Asian Journal of Energy. 12: 151-165.
41. Altinay G, Karogol E (2005) Electricity Consumption and Economic Growth Evidence from Turkey. Energy Economics. 27: 849-856.

42. Angell C (2005) U.S. Home Prices: Does Bust Always Follow Boom? FDIC outlook

43. Aqeel A, Butt MS (2001) The Relationship between Energy Consumption and Economic Growth in Pakistan. Asia-Pacific Development Journal 8: 101.

44. Asghar Z (2008) Energy-GDP relationship: A Causal Analysis for the Five Countries of South Asia. Applied Econometrics and International Development 8: 167-180.

45. Engle RF, Granger CWJ (1987) Co-integration and Error Correction: Representation, Estimation, and Testing. Econometrica 55: 251-276.

46. Erbaykal E (2008) Disaggregate Energy Consumption and Economic Growth Evidence from Turkey. International Research Journal of Finance and Economics 172-179.

47. Imran K, Siddiqui MM (2010) Energy Consumption and Economic Growth: A Case Study of Three SAARC Countries. European Journal of Social Sciences 16: $206-213$

48. Ishaque F (2008) Oil Price Tumbling, Pakistan and Gulf Economist 27 Oct-2 Nov, 2008.

49. Jamali BM, Shah A, Somaro JH, Shafiq K, Shaikh MF (2011) Oil Price Shocks: A Comparative Study on the Impacts in purchasing Power in Pakistan. Modern Applied Science.

50. Khan AM, Ahmed U (2009) Energy Demand in Pakistan: A Disaggregate Analysis. MPRA Paper No.15369.

51. Khan AM, Ahmed A (2011) Macroeconomic Effect of Global Food Oil Prices Shocks to the Pakistan Economy: A Structure Vector Autoregressive (SVAR) Analysis. Pakistan development review 50: 491-511.

52. Khalid M, Abbas F (2007) Energy Use for Economic Growth: Cointegration and Causality Analysis from the Agriculture Sector of Pakistan. The Pakistan Development Review 46: 1065-1073.

53. Levent K (2007) Testing Causal Relationship between Energy Consumption, Real Income and Prices: Evidence from Turkey. MPRA Paper 1: 1-29.

54. MacKinnon JG (1991) Critical Values for Cointegration Tests. In: Engle RF and Granger J, Long-run (eds), Economic Relationships: Readings in Cointegration. Oxford University Press.

55. Noor-e-Sehar (2011) Impact of Oil Prices on Economic Growth and Exports Earning: In the Case of Pakistan and India. The Romanian Economic Journal.

56. Noor S, Siddiqui MW (2010) Energy Consumption and Economic Growth in South Asian Countries: A Cointegrated Panel Analysis. International Journal of Human and Social Sciences 5: 921.

57. Hydrocarbon Development Institute of Pakistan, Ministry of Petroleum and Natural Resources. Government of Pakistan.

58. Pakistan Economic Survey. Islamabad: Ministry of Finance, Government of Pakistan.

59. Ran J, Voon JP (2012) Does Oil Price Shock Affect Small Open Economies? Evidence from Hong Kong, Singapore, South Korea and Taiwan. Applied Economics Letters 19: 1599-1602.

60. Sarfaraz S (2011) Oil companies of Pakistan. Karachi Institute of Technology and entrepreneurship.

61. Shahbaz M, Zeshan M, Afza T (2012) Is Energy Consumption Effective To Spur Economic Growth In Pakistan? New Evidence from Bond Test to Leve Relationship and Granger Causality Tests. MPRA paper no. 39734

62. Zhao HC, Yuan J, Kang JG (2008) Oil Consumption and Economic Growth in China: A Multivariate Cointegration Analysis. ICRMEM '08 Proceedings of the 2008 International Conference on Risk Management and Engineering Management. 